\title{
Telemonitoring of Brazilian Nursing homes before Coronavirus and COVID-19 Infections
}

\author{
Telemonitoramento a instituições de longa permanência para idosos frente às infecções por coronavírus e COVID-19
}

Telemonitorización de hogares para ancianos frente a las infecciones por coronavirus y COVID-19

Tânia Maria de Oliva Menezes' ORCID: 0000-0001-5819-0570

Adriana Valéria da Silva Freitas' ORCID: 0000-0003-1831-4537

Larissa Chaves Pedreira' ORCID: 0000-0001-8939-324X

Juliana Bezerra do Amaral' ORCID: 0000-0003-2355-9117

'Universidade Federal da Bahia. Salvador, Bahia, Brazil.

How to cite this article: Menezes TMO, Freitas AVS, Pedreira LC, Amaral JB. Telemonitoring of Brazilian Nursing homes before

Coronavirus and COVID-19 Infections.

Rev Bras Enferm. 2020;73(Suppl 2):e20200350 doi: http://dx.doi.org/10.1590/0034-7167-2020-0350

Corresponding author: Tânia Maria de Oliva Menezes E-mail: tomenezes50@gmail.com

EDITOR IN CHIEF: Dulce Barbosa ASSOCIATE EDITOR: Maria Elisabete Graziosi

Submission: 04-25-2020 Approval: 06-14-2020

\begin{abstract}
Objective: to report the experience of telemonitoring Brazilian nursing homes before coronavirus and COVID-19 infections. Methods: a descriptive experience report that occurred between March 18 and April 25, 2020 through telemonitoring nursing homes in Salvador, Bahia, following a script previously prepared for first contact and follow-up. The telemonitoring was carried out by professors from the School of Nursing of Universidade Federal da Bahia and Graduate Program students for four weeks. Results: thirty-two institutions were followed for four weeks. Some facilities and difficulties appeared during the monitoring. Final consideratios: as nursing homes are collective households, their residents are vulnerable to transmission of infections. In addition, the diversity of structures and economic, social and human resources needs of these locations reveal their fragility and urgency of public policies that address such diversities.
\end{abstract}

Descriptors: Aged; Homes for the Aged; Telemonitoring; Coronarivus Infections; Nursing

\section{RESUMO}

Objetivo: relatar a experiência de telemonitoramento de Instituições de Longa Permanência para Idosos frente às infecções por coronavírus e COVID-19. Métodos: relato descritivo da experiência ocorrida entre 18 de março e 25 de abril de 2020, através de telemonitoramento das instituições de Salvador, Ba, seguindo um roteiro previamente elaborado para primeiro contato e de seguimento. O telemonitoramento foi realizado por docentes da Escola de Enfermagem da Universidade Federal da Bahia e discentes do Programa de Pós-Graduação dessa escola, durante quatro semanas. Resultados: foram acompanhadas 32 instituições durante quatro semanas. Algumas facilidades e dificuldades se apresentaram no decorrer do monitoramento. Considerações finais: como as Instituições de Longa Permanência para Idosos são domicílios coletivos, seus residentes são vulneráveis a transmissão de infecções. Ademais, a diversidade de estruturas e necessidades econômicas, sociais e de recursos humanos desses locais revela sua fragilidade e urgência de políticas públicas que atendam tais diversidades.

Descritores: Idoso; Instituição de Longa Permanência para Idosos; Telemonitoramento; Infecções por Coronavírus; Enfermagem.

\section{RESUMEN}

Objetivo: informar la experiencia de telemonitorización de los Hogares para Ancianos frente a las infecciones por coronavirus y COVID-19. Métodos: informe descriptivo de la experiencia que tuvo lugar entre el 18 de marzo y el 25 de abril de 2020, a través de la telemonitorización de las instituciones de Salvador, Ba, siguiendo un guión previamente preparado para el primer contacto y seguimiento. La telemonitorización fue realizada por profesores y alumnos del Programa de Posgrado de la Escuela de Enfermería de la Universidade Federal da Bahía. Resultados: 32 instituciones fueron seguidas durante cuatro semanas. Algunas instalaciones y dificultades aparecieron durante el monitoreo. Consideraciones finales: como los Hogares para Ancianos son colectivos, sus residentes son vulnerables a la transmisión de infecciones. Además, la diversidad de estructuras y las necesidades de recursos económicos, sociales y humanos de estos lugares revela su fragilidad y la urgencia de las políticas públicas que abordan tales diversidades.

Descriptores: Ancianos; Hogares para Ancianos; Telemonitorización; Infecciones por Coronavirus; Enfermería. 


\section{INTRODUCTION}

Nursing homes (NHs) are places intended for the housing of elderly people, usually with some impairment of cognitive and functional capacity, requiring the attention of caregivers. Currently, $\mathrm{NHs}$ have been a target of concern for health authorities regarding COVID-19.

COVID-19 is an acute respiratory disease, sometimes severe, caused by the new coronavirus (2019-NCoV or SARS-CoV-2). The human infection caused by this virus is an international public health emergency ${ }^{(1)}$, and people residing in $\mathrm{NH}$ s are in a vulnerable situation due to old age; greater presence of comorbidities, with emphasis on hypertension, diabetes mellitus; heart diseases and lung diseases; immunosenescence; sharing collective environments; and dependence to perform daily activities. Thus, they need caregivers to provide care with unwanted proximity, when the intention is to prevent coronavirus infection.

With the outbreaks of COVID-19, actively monitoring potentially infected patients and implementing actions are necessary measures to prevent and control the virus, preventing its rapid spread $^{(2)}$, especially when it comes to vulnerable elderly people and their caregivers.

The lethality of people affected by COVID-19 varies according to the country, but it is evident that elderly individuals and people with chronic comorbidities are the ones with the most complications ${ }^{(1)}$. A study that aimed to analyze the clinical characteristics of elderly people with pneumonia associated with COVID-19 found a mortality rate of $5.3 \%$ in these people and a mortality rate of $1.4 \%$ in the others under 60 years old. Moreover, hypertension and diabetes prevailed as comorbidities and symptoms such as cough, sputum and hyperthermia(3). Although it was a study with a small population, like most on this topic at the moment, these findings are also corroborated by other authors ${ }^{(3-5)}$, in addition to being already noticed in the statistics presented by the media.

In the pandemic scenario of COVID-19, with high lethality in $\mathrm{NH}^{(4,6)}$, the Center for Studies and Research for Elderly Individuals (Núcleo de Estudos e Pesquisa do Idoso, abbreviated NESPI) of UFBA School of Nursing (Escola de Enfermagem da UFBA, abbreviated EEUFBA) discussed a proposal for remote monitoring for these institutions. NESPI developed a script for diagnosing the situation in NHs in Salvador, following and daily monitoring, when necessary, in order to contribute to the situation of institutionalized elderly people; take information to their caregivers related to their main forms of transmission and preventive measures to spread the infection, updating the situation of these institutions before the pandemic.

Concomitant with the articulation already initiated at NESPI, EEUFBA together with professional associations and organizations created, on March 20, the Nursing Committee for Coping with COVID-19 in Bahia (Comitê de Enfermagem para Enfrentamento da COVID-19, abbreviated CEEC), aiming to meet the demands of the nursing team before the pandemic. CEEC, in turn, created working groups according to the specificities of the different and diverse demands that came. We, NESPI professors, accepted the invitation to join CEEC regarding the TG (Thematic Group) Health of Elderly Individuals, thus articulating what had already started in that center.

\section{OBJECTIVE}

To report the telemonitoring experience of $\mathrm{NHs}$ before coronavirus and COVID-19 infections.

\section{METHODS}

This is a descriptive experience report developed by four professors from the EEUFBA, with the collaboration of five master's students and five PhD from the Graduate Program in Nursing and Health (PPGENF/EEUFBA); all were members of NESPI. The report describes a month of the experiment, which took place between March 18 and April 25, 2020, with 10 days for planning actions and four weeks for telemonitoring.

In the first week, the proposal to be implemented and the script for telemonitoring were discussed among professors, covering three aspects related to: 1 . Elderly people; 2 . Professionals of the institution; 3. Institution. The script was constructed with 10 questions covering the three aspects. Some questions had consequences, depending on the answer obtained.

Regarding elderly individuals, the script contained questions related to their general condition; presence or absence of respiratory symptoms and, if so, which ones; vaccination status for influenza; occurrence or not of behavior change in some elderly person due to the suspension of visits. As for professionals, the questions were related to the general state; knowledge and guidance on COVID-19; occurrence of leave due to suspected case of COVID-19. Regarding the institution, the questions focused on the situation of group visits and activities at the site, a professional category active at the time; if they had personal protective equipment (PPE); whether there was planning in the face of suspected cases; and if they had any demand. All this planning took a week.

The list of NHs in Salvador, which would be monitored, as well as their contacts, was obtained by NESPI through a request to the president of the State Council for Elderly Individuals and a member of the Municipal Office for Elderly Individuals. At that time, the divergence of information between the sectors was identified, as there was a distinction in the registration and quantitative of $\mathrm{NHs}$. The first had 26 records, and the second, 46. When comparing and analyzing the lists, we observed some institutions present in both, and others, present only in one or the other, totaling 39 institutions to be contacted through telephone calls.

The telemonitoring proposal was presented to NESPI members, aiming to identify those interested in participating in the action. A graduate student, six master's students and five doctoral students attended the call. These, adding two professors, completed a group of 14 people involved in the telemonitoring of NHs in Salvador. Then they were distributed from one to four institutions to each of the members, with the respective telephone number as well as the electronic address of those who owned it. The students were instructed that, when making the calls, they should request the presence of the person responsible for the institution to answer the instrument.

Twelve days after the script was drawn up and contacts started, on April 1, NESPI was invited to participate in the meeting, representing CEEC. At this meeting, the Health Office of the State of 
Bahia was represented through the Primary Care Directorate, Care Management Directorate and State Reference Center for Elderly Health Care (Centro de Referência Estadual na Atenção a Saúde do Idoso, abbreviated CREASI); Office of Justice, Human Rights and Social Development and the Social Action and Combat Poverty Office, aiming to integrate actions to coping with COVID-19. At this meeting, the proposal initiated by NESPI for telemonitoring the NHs of Salvador, Ba, was presented and adopted by the members through a script created and already used by NESPI. Thus, distribution of the institutions was defined, and contact and monitoring of $\mathrm{NH}$ s belonging to other municipalities in Bahia was under the responsibility of the other representations. Finally, two more questions were included in the monitoring script based on the suggestions of CREASI members.

After this meeting, the Secretary of Health of the State of Bahia signed Ordinance 133, published on April 3, 2020, creating the Inter-Sectoral Commission for Monitoring NHs (CIANH) in the state of Bahia to monitor health actions in institutions through teleorientation, composed of all the institutions previously presented.

From the meeting when the CIANH was introduced, NESPI was already in the second week of the experience, when contact with the institutions started. At the end of the first week of contact, the follow-up script was used. Among others, it was questioned the occurrence of any death in the institution in the last week, if there were any suspected cases of COVID-19, whether related to elderly individuals or professionals. If so, $\mathrm{NH}$ should be monitored daily by a CREASI physician or nurse. If there was no positive case, or a suspicion of an elderly person or professional, calls were made weekly. In the third, fourth and fifth week, the telephone contact with the institutions continued applying the follow-up script, or first contact script, with the identification of new $\mathrm{NHs}$.

All information was transcribed into a spreadsheet available in the commission system, for monitoring NHs across the state, and daily information being sent to the health departments of the contacts made.

The report was based on references from authors dealing with the topic, which were consulted through a search conducted at Scientific Electronic Library Online (SciELO), Medical Literature Analysis and Retrieval System Online (MEDLINE), Cumulative Index to Nursing and Allied Health Literature (CINAHL); Scopus Info Site (Scopus), in addition to official websites of the Ministry of Health and the World Health Organization.

\section{RESULTS}

Monitoring was based on this premise, which guided the way to initiate telephone contact with NHs. In the first week of telephone contact, $23 \mathrm{NHs}$ answered the call. It was not possible to contact 16 institutions, as the phone was not answered and the email sent did not get a response (02); the phone number did not exist or the phone was busy (09); they answered the phone, but the person responsible for the information was not at the Institution, or was present, but at the time he or she could not answer (05).

After the first week of telephone contact, the second week of the experience, some institutions appeared that were not registered in the lists received. Some of these were private, as well as two institutions with only one headquarters in the initial list; however, when making contact, they informed that they also had another headquarters.

In the third week of the experience, telephone contacts continued, with the $23 \mathrm{NHs}$ who answered the first contact, 19 responded to the follow-up script 1. Four institutions did not answer calls for this moment, either because they did not answer the phone (3 $\mathrm{NHs}$ ), or due to the manager's unavailability to respond to the script at the time of the call $(1 \mathrm{NH})$. These unsuccessful calls were made more than once during the week. Moreover, a first contact was made with three new institutions, which had not been contacted previously.

Still in the second week of telephone contact, three $\mathrm{NH}$ s were identified with suspected cases of COVID-19. One was related to elderly individuals, and two to professionals, who started to have daily monitoring.

Considering the demands already raised, the professors involved with the collaboration of NESPI undergraduate scholarship holders prepared a booklet with guidelines for $\mathrm{NH}$ workers on COVID-19. This booklet talked about transmission, signs and symptoms, preventive measures, isolation of suspected residents, use of PPE and how to make your own mask.

In the fourth week of the experiment, telephone contacts were continued with the $26 \mathrm{NH}$ s monitored in the previous week, plus four new institutions. A new CIANHs meeting was held to evaluate the actions. A new list made available by the Public Ministry with $40 \mathrm{NH}$ in Salvador was presented, and the ITG (Interprofessional Technical Group) contacted 10 new institutions, which were referred by the commission.

Of the 10 new institutions contacted, in nine it was not possible to obtain information, due to the available phones not answering, being out of the area or hearing the information that the phone did not exist. Through the weekly report sent to the commission, the difficulty with nine new contacts was reported. Even before the pandemic, it was evident that some $\mathrm{NH}$ s feel watched and unwilling to answer questions, considering the number of negatives to meet the proposal of two; and four did not answer the script on the first call.

In the fifth week of the experiment, the fourth week of telemonitoring, 30 follow-up contacts and one contact with a new institution were made. One NH did not answer the phone provided, totaling the week with 31 contacts. Some institutions were already more familiar with the connection, considering continuity of the action. We did not get feedback on the new numbers of the nine institutions unavailable in the previous week.

During the entire period of the experiment, a professor was responsible for receiving the completed scripts and posting them in the spreadsheet available in the system. The purpose of this spreadsheet is to monitor NHs across the state and provide daily information to the committee that prepares a daily report and sends it to competent bodies.

After completing five weeks of activities, the team assessed the results achieved and decided to continue the action, considering the importance of monitoring $\mathrm{NH}$ in the capital.

\section{DISCUSSION}

The best way to prevent COVID-19 is by taking actions such as hand hygiene and social isolation to prevent the virus to 
spread $^{(7)}$. NH telemonitoring is important and, in the face of a pandemic situation, even more so. In these institutions, elderly people are vulnerable, respiratory problems such as pneumonia are frequent, due to chronic diseases, problems with swallowing, agitation, decreased mobility, dementia, among others. The presence of COVID-19 in NHs can thus have a devastating effect as elderly people are often affected by pneumonia or other respiratory diseases ${ }^{(8)}$.

An editorial comments on the weight of COVID-19 for older people in low- and middle-income countries, and points out that some $\mathrm{NHs}$ are like an incubator for infections, given the small space, where people are often close. Given the dependence of these elderly people, the infection of their caregivers would be equally devastating for the well-being and survival of residents ${ }^{(4)}$.

Another worrying situation is the effect of social isolation on institutionalized people, often affected by dementia, delirium and other behavioral changes ${ }^{(9)}$. These changes can be confused with an infectious condition, exposing elderly individuals to the risk of anxiety and depression with its consequences, in addition to bringing difficulties for caregivers to maintain isolation and control the situation ${ }^{(8)}$.

The isolation related to institutionalized elderly people has been a topic discussed in studies that deal with depression, linking to a perspective that institutionalization itself can promote the isolation of elderly people, as it contributes to the distancing of family members ${ }^{(10)}$. However, isolation can be a protective measure, when the focus is no longer on the relationship between elderly individuals and family members, but on the issue of their survival due to the threat of a health situation. This situation worsens when the people affected are elderly. NHs must ensure the maintenance of isolation, and also ensure that residents have less consequences regarding emotional aspects as well.

An experience reported in Singapore says that, in the face of fear of coronavirus infection, NHs refer all elderly people with fever and respiratory symptoms to the health service. At the hospital, these people are isolated until the test is performed, which can be repeated twice. If not, they can be transferred to a ward. At discharge, $\mathrm{NHs}$ request a letter from the hospital proving that the elderly person has not tested positive for the infection, before accepting him or her again. In the case of Singapore, the health system was able to receive these people; however, in the case of Brazil, the institution of horizontal isolation tries to protect the health system from collapse, and these elderly people in $\mathrm{NHs}$ remain isolated while clinically stable ${ }^{(8)}$.

In this sense, the COVID-19 pandemic opens space for a necessary discussion for NHs. Currently, these institutions are understood as devices inserted in the Unified Social Assistance System (Sistema Único de Assistência Social), under the responsibility of the Ministry of Social Development and Fight against Hunger (Ministério do Desenvolvimento Social e Combate à Fome). However, the need to expand this compression and support $\mathrm{NH}^{\prime} \mathrm{S}$ in relation to deepening health knowledge is present, being presented through experiences of other countries in caring for elderly individuals during the COVID-19 pandemic, and thus, placing them also linked to the Brazilian Health System (Sistema Único de Saúde, abbreviated SUS).
Thus, monitoring becomes important considering the invisibility of these situations and collaborates with $\mathrm{NHs}$, taking support and meeting identified demands, within the possibilities, in order to protect elderly individuals and professionals as much as possible.

\section{Facilities}

We highlight the involvement of NESPI members in the action and the submission of the scripts within the established deadlines. Also, the participation of the Commission and resolution of important demands raised, such as the lack of vaccination for influenza in some institutions and discovery of $\mathrm{NH}$ contacts that were not possible with what had been initially available.

\section{Difficulties}

The first difficulty was related to some unanswered phone numbers, using Google, to discover contacts. The commission was also signaled to $\mathrm{NH}$ without contacts by non-existent phones, and the return of new contacts occurred in a prolonged time, generating absence of early contact with the institution.

With regard to institutions, the absence of PPE in some $\mathrm{NHs}$ is a reality and signals the risk that professionals working in these places are exposed in the exercise of their profession. With the demand raised, $\mathrm{NH}$ awaits resolution, which was not always possible to meet before the scarcity of equipment.

Another difficulty presented is related to the unavailability of professionals to answer the call when contacts were made. In some institutions, at least four calls were required to respond to the script. This difficulty was more present after the follow-up, when several $\mathrm{NHs}$ scheduled the response to the script for the next day, making it more difficult to monitor it quickly, in the face of suspected or confirmed cases.

\section{Study limitations}

The study was limited in relation to not being able to meet some demands evidenced during the monitoring, although this was not the objective of the action. In addition, the lack of response from some institutions to the connections made is also considered a limitation. Therefore, it was not possible to characterize the situation of facing them according to all aspects outlined in the scripts.

\section{Contributions to nursing}

In telephone contacts, guidance on prevention and care before the disease was given, in addition to technical notes and information made available by email to institutions that had an electronic address, providing opportunities to expand the knowledge of professionals.

In addition, for nursing, the experience of monitoring $\mathrm{NHs}$ during a pandemic revealed the importance of their knowledge regarding the valorization of nursing care; based on consistent theoretical references since the creation of the profession, which needs to be increasingly strengthened through teaching, research and extension. 


\section{FINAL CONSIDERATIONS}

Infection with the new coronavirus represents a serious health problem for elderly individuals living in NHs. Monitoring these institutions helped in the early detection of suspected cases of the virus in professionals and elderly individuals. Also, when clarifying doubts of the professionals during the contacts made.
Considering the pandemic situation, the importance of several health professionals working in $\mathrm{NHs}$ is evident. However, some of them only have caregivers, others, caregivers and nursing technicians, showing urgency in the review of professionals who must be part of the minimum team working in $\mathrm{NHs}$, with emphasis on nurses.

The experience can contribute to other states, since the scripts can be shared with nursing professionals who work in other $\mathrm{NHs}$, helping to monitor these institutions.

\section{REFERENCES}

1. Ministério da Saúde (BR). Nota Técnica ${ }^{\circ}$ 8/2020-COSAPI/CGCIVI/DAPES/SAPS/MS. Prevenção e controle pelo novo coronavírus (SARS-Cov-2) a serem adotadas nas Instituições de Longa Permanência para Idosos[Internet]. 2020[cited 2020 Apr 12]. Available from: http://189.28.128.100/dab/docs/portaldab/documentos/notatecnica82020COSAPICGCIVIDAPESSAPSMS02abr2020COVID-19.pdf

2. McMichael TM, Currie DW, Clark S, Pogosjans P, Kay M, Schwartz NG, et al. Epidemiology of Covid-19 in a Long-Term Care Facility in King County, Washington. N Engl J Med. 2020; 382:2005-2011. doi: 10.1056 / NEJMoa2005412

3. Liu K, Chen Y, Lin R, Han K. Clinical feature of COVID-19 in elderly patients: A comparison with young and middle-aged patients. J Infect. 2020;pii:S0163-4453(20)30116-X. doi: 10.1016/j.jinf.2020.03.005

4. Lloyd-Sherlock P, Ebrahim S, Geffen L, McKee M. Bearing the brunt of covid-19: older people in low and middle income countries. BMJ 2020;368:m1052. doi: 10.1136/bmj.m1052

5. D'Adamo H, Yoshicawa T, Ouslander JG. Coronavirus Disease 2019 in Geriatrics and Long-Term Care: the ABCDs of COVID-19. J Am Geriatr Soc 2020;00:1-6. doi: 10.1111/jgs.16445

6. Ministério da Saúde (BR). Nota técnica GVIMS/GGTES/ANVISA № 05/2020. Orientações para a prevenção e o controle de infecções pelo novo coronavírus (sars-cov-2) em Instituições de Longa Permanência para Idosos (ILPI)[Internet]. 2020 [cited 2020 Apr 12]. Available from: http://portal.anvisa.gov.br/documents/219201/4340788/NOTA+TE\%CC\%81CNICA+8+-+CORONAVI\%CC\%81RUS+2. pdf/75797abb-1bf5-4eb6-99e1-a1238269e30a

7. Ministério da Saúde (BR). Nota Técnica GVIMS/GGTES/ANVISA № 04/2020. Orientações para serviços de saúde: medidas de prevenção e controle que devem ser adotadas durante a assistência aos casos suspeitos ou confirmados de infecção pelo novo coronavírus (SARS-CoV-2). (atualizada em 31/03/2020)[Internet]. 2020[cited 2020 Apr 13]. Available from: http://portal.anvisa.gov.br/ documents/33852/271858/Nota+T\%C3\%A9cnica+n+04-2020+GVIMS-GGTES-ANVISA/ab598660-3de4-4f14-8e6f-b9341c196b28

8. Tan LF, Seetharaman S. Preventing the Spread of COVID-19 to nursing homes. Experience from a Singapore Geriatric Center. J Am Geriatr Soc. 2020;68(5):942. doi: 10.1111/jgs.16447

9. Armitage R, Nellums LB. COVID-19 and the consequences of isolating the elderly. Lancet Public Health. 2020;pii:S2468-2667(20)30061-X. doi: 10.1016/S2468-2667(20)30061-X

10. Oliveira LG, Rodrigo J. Depressão em idosos institucionalizados: uma revisão de literatura. Rev JRG Est Acad[Internet]. 2020 [cited 2020 Apr 20];III(6). Available from: http://www.revistajrg.com/index.php/jrg/article/view/114/104 